\title{
Geochemistry of phosphatic nodules as a tool for understanding depositional and taphonomical settings in a Paleolithic cave site (San Teodoro, Sicily)
}

\author{
Gerlando Vita (D ${ }^{1 *}$, Vittorio Garilli (D) ${ }^{2}$, Mirko Andrea Vizzini ${ }^{3}$, Renato Giarrusso (1D ${ }^{3}$, \\ Angelo Mulone ${ }^{3}$, Massimiliana Pinto Vraca ${ }^{4}$, Valeria La Parola (iD ${ }^{5}$, Pierluigi Rosina (iD) ${ }^{6}$, \\ Laura Bonfiglio (D) ${ }^{7}$, and Luca Sineo (1D ${ }^{8}$
}

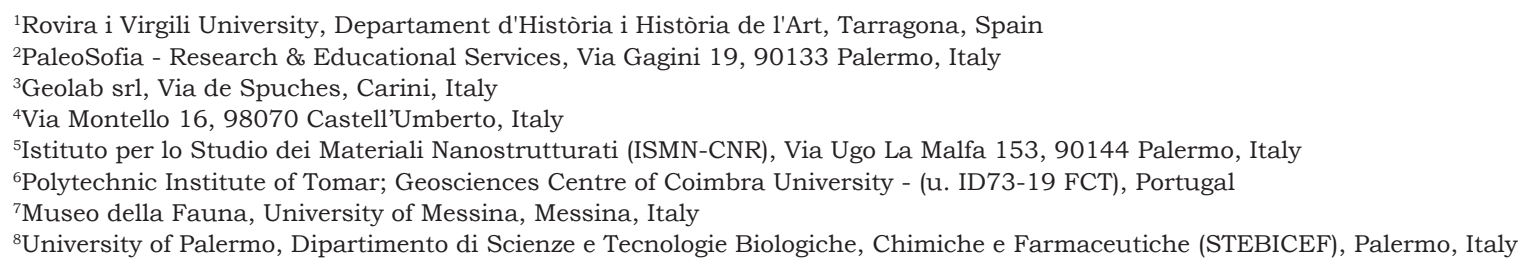

\begin{abstract}
Interpreting depositional settings of cave sites is generally problematic, especially in absence of paleontological/archaeological evidence. This is the case of some deposits at San Teodoro Cave (Sicily), a key site for the Mediterranean Paleolithic. In a stratigraphic level interrupted by a carbonatic concretion, phosphatic nodules are present only in the part enclosed between the concretion and the cave wall. The discovery of these nodules combined with the punctual lack of fossils had initially suggested an erosion phenomenon and subsequent formation of nodules at a vadose level. Here we show the usefulness of an integrated, geochemicalpaleoecological approach in defining stratigraphy and paleoenvironmental reconstructions. XRD, ICP-OES, ATR-FTIR and EDS analyses allowed the formulation of a new hypothesis regarding the origin of the nodules, the depositional dynamics, and the role played by the guano produced by an extensive colony of bats. The role of barium and rubidium in detecting taphonomical processes has been highlighted.
\end{abstract}

Keywords: Geochemistry, phosphate nodules, bat guano, cave taphonomy, variscite, Paleolithic

Received 2 July 2021; Revised 30 August 2021; Accepted 5 September 2021

Citation: Vita G., Garilli V., Vizzini M.A., Giarrusso R., Mulone A., Pinto Vraca M., La Parola V., Rosina P., Bonfiglio L., Sineo L., 2021. Geochemistry of phosphatic nodules as a tool for understanding depositional and taphonomical settings in a Palaeolithic cave site (San Teodoro, Sicily). International Journal of Speleology, 50(3), 249-261. Tampa, FL (USA) ISSN 0392-6672 https://doi.org/10.5038/1827-806X.50.3.2398

\section{INTRODUCTION}

The stratigraphy and environmental reconstructions of depositional settings in cave sites could be of difficult understanding and may hide pitfalls. Dishomogeneous fossil assemblages, small-scale changes in the sedimentation, and the crypticity of post-depositional processes could become the main reasons for misunderstanding in the stratigraphic correlations and the identification of depositional hiatus and may complicate the paleoenvironmental issues (for a review see Farrand, 2001). In particular, the lack of a paleontological content, above all when delimited to an area of a cave deposit, can cause incorrect interpretations in stratigraphic and paleoenvironmental reconstructions. The patchy distribution of fossil bones in cave deposits may be due to differential dissolution (Weiner et al., 1993; Karkanas et al., 1999; Quattropani et al., 1999; Weiner et al., 2002; Miller et al., 2016) in conditions of increased acidity at certain parts of the deposits (Stiner et al., 2001), erosion processes, or lack of frequentation of bone accumulating animals such as hyenas or humans (Mangano, 2011; Garilli et al., 2020b). In such contexts, especially when cave deposits undergo (paleo)biological/taphonomical processes, a geochemical approach may be decisive in the paleoenvironmental and stratigraphical reconstructions.

Here we report an example of how this approach can help in solving stratigraphic and taphonomical problems in a cave setting arising from the study of some Late Pleistocene deposits in the San Teodoro 
Cave (Figs 1A, B), in north-eastern Sicily, Italy, a key site for the Paleolithic of the Mediterranean area because of its paleontological and archaeological contents (Maviglia, 1941; Graziosi, 1947; Mangano et al., 2005; Mangano \& Bonfiglio, 2005; Bonfiglio et al., 2008). At the innermost side of this site, the sterile part of unit B, containing phosphatic nodules, was interpreted as the result of erosion processes and subsequent deposition in lacustrine conditions (Mangano \& Bonfiglio, 2005; Mangano et al., 2005; Mangano et al., 2020). Mangano and Bonfiglio (2005) regarded this sterile deposit as a new stratigraphical unit, the so-called unit $\mathrm{C}$.

We present a new paleoenvironmental interpretation of the genesis of the phosphatic nodules found in the San Teodoro site showing a further cave case in which the formation of authigenic minerals are linked to biological processes and chemical variations.

Our geochemical approach will be particularly focused on the identification of the authigenic mineral that formed in unit $\mathrm{C}$ of Mangano and Bonfiglio (2005) in the San Teodoro Cave. The identification of this kind of minerals helps to reconstruct the original chemical environments in paleo-archaeological deposits (Karkanas et al., 2000). For example, hydrated phosphate of calcium and aluminum, such as crandallite $\mathrm{CaAl}_{3}\left(\mathrm{PO}_{4}\right)(\mathrm{OH})_{5}\left(\mathrm{H}_{2} \mathrm{O}\right)$ and montgomeryite $\mathrm{Ca}_{4} \mathrm{MgAl}_{4}\left(\mathrm{PO}_{4}\right)_{6}(\mathrm{OH})_{4} 12\left(\mathrm{H}_{2} \mathrm{O}\right)$, hydrated alkali iron-aluminum, such as taranakite $\mathrm{H}_{6} \mathrm{~K}_{4} \mathrm{Al}_{5}\left(\mathrm{PO}_{4}\right)_{8} \cdot 18 \mathrm{H}_{2} \mathrm{O}$, and hydrated phosphate of aluminum, such as variscite $\mathrm{AlPO}_{4} \cdot 2 \mathrm{H}_{2} \mathrm{O}$, could be used as a marker of taphonomical acidification processes resulting in sediment sterility (Goldberg \& Nathan,1975; Fiore \& Laviano, 1991; Quattropani

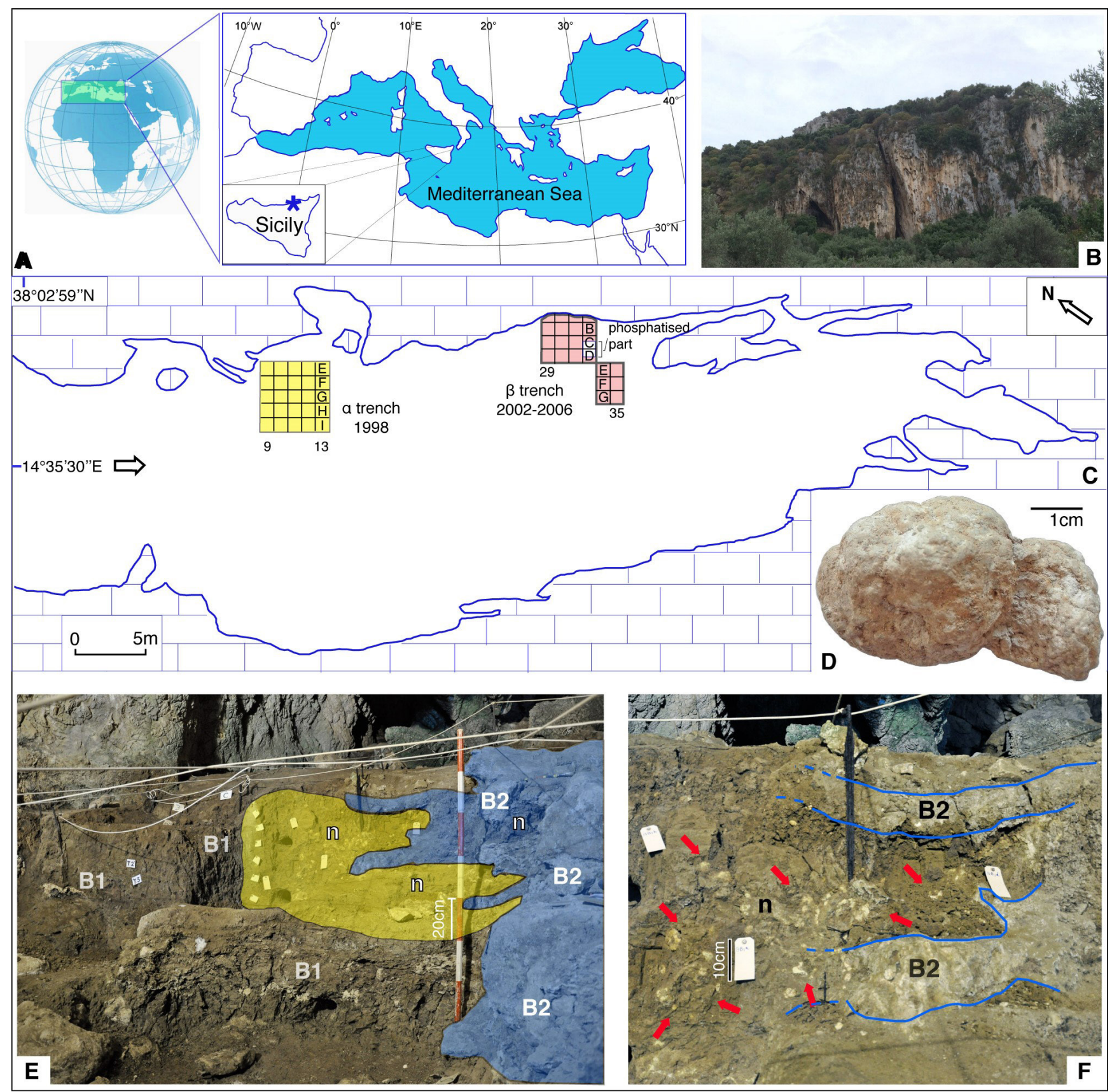

Fig. 1. A) General location of the study site, the San Teodoro Cave (Messina, NE Sicily). B) The study site from the outside. C) Plan of the Cave with the location of $\alpha$ and $\beta$ trenches and the phosphatized part. D) One of the phosphate nodules (sample B1A2) detected from the $\beta$ trench. E) General view of the $\beta$ trench with the location of nodules (yellow area with "n", the so-called unit $C$ of Mangano and Bonfiglio, 2005); layer B1 and carbonate concretions B2 (light blue area). F) Detail of the $\beta$ trench showing nodules (arrows in the $n$ area) and part of the carbonate concretions B2 outlined by the light blue line. 
et al., 1999; Karkanas et al., 2000; 2010; Stiner et al., 2001; Onac et al., 2004; Shahack-Gross et al., 2004; Onac, 2012). With the same aim, we will show the result of the investigation of trace elements detected in the innermost part of the study site. Trace elements can provide additional information useful for paleoenvironmental reconstructions (Canti \& Huisman, 2015) and can shed light on the original conditions that led to the formation of phosphatic minerals (Siy, 1988; Westerman, 2007).

\section{GEOLOGICAL SETTING}

The study area belongs to the geological northeastern sector of Sicily, an area characterized by the overthrust of the Kabilo-Calabridi tectonic units of the Calabrian-Peloritan arc over the Sicilid units of the Sicilian Maghrebid chain. In the area, the deepest tectonic unit is Longi Taormina, which consists of an epimetamorphic Paleozoic basement on which sedimentary successions lie discordantly. These successions consist of limestones and calcilutites (Lower Giurassic); Scaglia (Cretaceous-Eocene); Flysch of Frazzanò (Eocene-Oligocene) and Flysch of Capo d'Orlando (Oligocene-Miocene). These units are superimposed on the tectonic unit Sicilide, mainly the flysch of Monte Soro (Albian-Cenomanian), consisting of alternations of quartz-arenites, feldspathic sandstone and shales. The study site, at Pizzo Castellaro (Acquedolci, Messina), is a cave formed in the Lower Giurassic limestones. The longer axis of the San Teodoro site follows the NNW-SSE fault-system orientation. This indicates that karstic processes along a fault line led to the formation of the cave (Lentini et al., 2000; Giunta et al., 2013). The most recent formation is represented by Pleistocene deposits, which consist of marine gravels, greyyellowish sands and conglomerates (Esu et al., 2007).

\section{THE SAN TEODORO SITE}

This site bears important deposits for the studies of the Mediterranean Paleolithic (Maviglia, 1941; Graziosi, 1947; Garilli et al., 2020a; Garilli et al., $2020 b)$ and records one of the earliest signals of human colonization of Sicily (D'Amore et al., 2009).

A few excavations, performed between the end of the $19^{\text {th }}$ and the early decades of the $20^{\text {th }}$ century (Garilli et al., 2020b with references), shed light on the stratigraphy of the site, whose succession is today visible at the a and $\beta$ trenches, respectively excavated close to the entrance and in the inner part of the cave (Bonfiglio et al., 2001, 2008). According to the most recent studies (e.g., Mangano \& Bonfiglio, 2005; Bonfiglio et al., 2008; Garilli et al., 2020b), two main units were recognised: a younger, late Epigravettian, archaeological unit A (the Layer PAL of Garilli et al., $2020 b)$ cropping out only at the a trench and bearing human food remains and artefacts; an older, generally fossiliferous, Late Pleistocene unit B cropping out in the $\alpha$ and $\beta$ trenches and bearing a diverse mammal fauna (San Teodoro/Pianetti faunal complex) including Sus scrofa, Cervus elaphus siciliae, Crocuta crocuta spelaea, Palaeoloxodon mnaidriensis, Bos primigenius siciliae, Bison priscus siciliae, Equus hydruntinus, and a huge amount of coprolites (e.g., Anca, 1860; Vaufrey, 1929; Bonfiglio et al., 2008; Mangano \& Bonfiglio, 2005; Mangano et al., 2005; Yll et al., 2006; Mangano, 2011). During the late Epigravettian, about 15 kyr ago (Mannino et al., 2011), four to six humans were buried, likely simultaneously, in sediments of unit B, now exposed in the a trench (Maviglia, 1941; Graziosi, 1947; Garilli et al., 2020a, b).

As for the detailed stratigraphy of the $\beta$ trench, which is our main subject of study, Bonfiglio et al. (2008) proposed the following stratigraphy of the unit B: a clayey basal layer (B3) and a few centimeters thick carbonate concretion $(\mathrm{Cl})$ dated to $32 \pm 4 \mathrm{kyr}$, both cropping out at the west side of the trench; an upper, clayey-silty sandy layer (B1), generally rich in mammal remains. An aragonitic calcrete, B2, occurs in the sub-central part of the trench (Fig. 2), in lateral contact with layer B1. Although calcretes are common in arid soils in open land, they can also be present within cave soils and sediments (Matthews et al., 2019; Smith et al., 2020; Vita, 2021). B2 is characterized by a brecciated structure and fingerlike expansions and contains numerous, $2-3 \mathrm{~cm}$ long, terrigenous inclusions with the longer axis subparallel horizontal. These inclusions contain bacterial structures, fecal spherulites, fragments of terrestrial gastropods, numerous bone fragments and a high percentage of clay (Vita, 2021). All these elements suggest that B2 formed in the capillary fringe within part of the pre-existing sediment of layer B1. The presence of fecal spherulites in carbonate concretion (Vita, 2021) indicates alkaline conditions, as these elements can be preserved only in environments with high $\mathrm{pH}$ (Brochier et al., 1993). The part of B2 in contact with the phosphatized area shows signs of probably chemical alteration, which are sometimes not very evident due to a large amount of terrigenous component of the concretion. B2 contained an Equus hydruntinus bone, dated to 21-23 kyr BP based on $\mathrm{U} / \mathrm{Th}$ analysis (Antonioli et al., 2014), and formed within the B1 layer during the Last Glacial Maximum (LGM) according to Vita (2021). In the eastern part of the $\beta$ trench, within the B1 layer, Mangano et al. (2005) detected a sterile unit (the unit C of Mangano \& Bonfiglio, 2005) with phosphatic "white-yellowish pisolith-like elements" with a diameter of few centimeters. According to these authors, the unit $\mathrm{C}$ is separated from the underlying unit B by an irregular, somewhere sub-vertical surface, interpreted as the result of erosion processes. Mangano and Bonfiglio (2005) suggested that these pisolithic-like elements, having a phosphatic composition, formed in a vadose level located above a water table inside the cave. Based on these considerations Mangano et al. (2020) reconstructed paleoenviromental conditions involving the presence of a paleolake inside the cave.

The fossil assemblage found in layer B1 is also known for small vertebrates such as bats and rodents. Interestingly, the highest abundance of bats has been reported from the eastern side of the $\beta$ trench (Bonfiglio et al., 2008). 


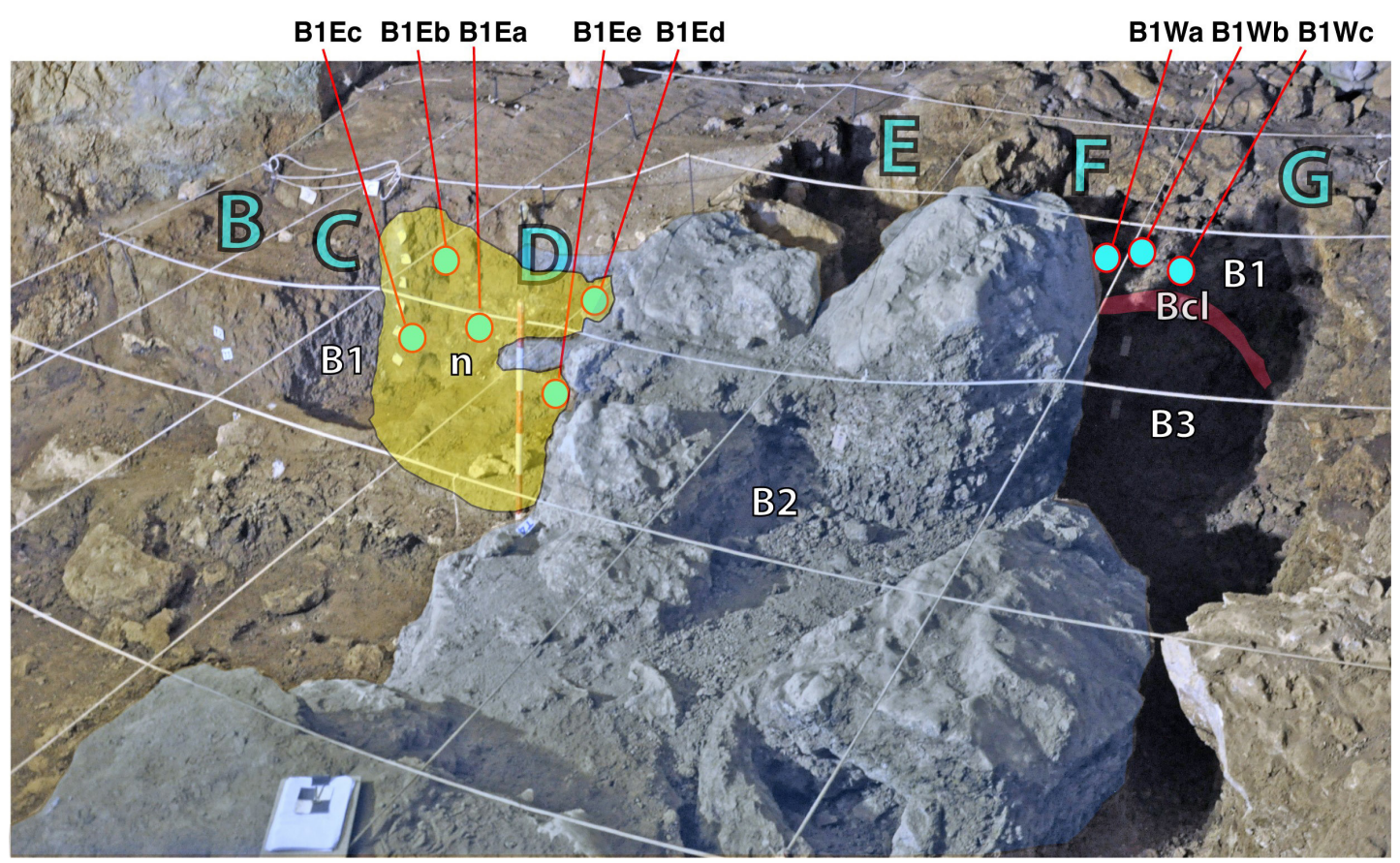

Fig. 2. Location of Late Pleistocene sediment samples at the east (squares $B, C, D$ ) and west (squares $E$, F, and G) sides of the $\beta$ trench at the San Teodoro site (Messina, NE Sicily). Note the stratigraphy of the unit B of Bonfiglio et al. (2008): the basal layer B3, the $32 \mathrm{kyr}$-old flowstone Bcl, the layer B1 and the younger calcrete B2 (highlighted in blue), which formed within the B1 layer. The yellow area, marked by the letter $\mathrm{n}$, roughly indicates the phosphatized area, namely the so-called unit C of Mangano \& Bonfiglio (2005).

\section{MATERIAL AND METHODS}

Three nodules (B1A1, B1A2, B1B) were collected from bulk samples (B1Ea, B1Eb, B1Ec, B1Ed, B1Ee of the layer B1 at the east side of the cave (Fig. 2), at the $\beta$ trench. Subspherical earthy nodules have a size ranging from $2 \mathrm{~mm}$ up to $8 \mathrm{~cm}$ (Fig. 1D). They have a yellowish-white color on the surface when exposed to air, in fresh fracture they are white and pulverulent. Since the east and west parts of B1 formed a continuous layer before the formation of the carbonate concretion B2 (Fig. 2), we analyzed and compared three massive samples $(\mathrm{B} 1 \mathrm{Wa}, \mathrm{B} 1 \mathrm{~Wb}$, B1Wc) collected from the western part (Fig. 2) with those taken from the eastern, phosphatized part of the same trench. A further nodule (B1X) collected during the 2006 excavation from the unit $\mathrm{C}$ of Mangano \& Bonfiglio (2005) was also studied. One slice, about 1 $\mathrm{cm}$ thick, with flat faces, was cut from two phosphate nodules (B1A1 and B1B) along the maximum diameter. Each slice was passed in the ultrasonic bath and dried in an oven at $30^{\circ} \mathrm{C}$. Two portions of the slices were mounted on stubs for EDS-SEM (energydispersive X-ray spectroscopy-scanning electron microscope) analyses. Half of each nodule was ground and homogenized. From each pulverized nodule, four aliquots were taken, two for the X-ray diffraction (XRD), one for the ICP-OES (inductively coupled plasma optical emission spectroscopy) and one for FTIR (Fourier-transform infrared spectroscopy). For each soil sample analyzed $1 \mathrm{~kg}$ was homogenized and quartered; one of these four portions obtained was further quartered, homogenized and ground. From each pulverized sediment, two aliquots were taken, one for the XRD and another for the ICP-OES.

XRD have been initially performed by PANalytical X'pert Pro to characterize the mineralogy of investigated samples. XRD analyses have been conducted on nodules B1A1, B1AB, and B1X, XRD and on sediment samples $\mathrm{B} 1 \mathrm{Wa}, \mathrm{B} 1 \mathrm{~Wb}, \mathrm{~B} 1 \mathrm{Wc}$, and $\mathrm{B} 1 \mathrm{Ea}, \mathrm{B} 1 \mathrm{Ec}, \mathrm{B} 1 \mathrm{Ed}$, and B1Ee. For the sediments, we used the finer fraction (less than $2 \mathrm{~mm}$ ) to avoid interference of nodules in the XRD of tout venant. Since these analyses did not allow an exhaustive mineralogical characterization of the phosphate in the studied nodules, a further diffractometer provided with a Bruker goniometer using Ni-filtered $\mathrm{Cu} \mathrm{K} \alpha$ radiation and graphite monochromator was subsequently used for the study of nodules B1A1 and B1B. A proportional counter and $0.05^{\circ}$ step size in $2 \theta$ 210 were used.

Fourier transform infrared (ATR-FTIR) spectra of samples were collected using a Bruker Alpha FTIR, Opus 7.5 software, spectrometer employing an ATR (Attenuated Total Reflection) sampling device. The ATR-FTIR spectrometer was equipped with a global source, a $\mathrm{KBr}$ beam splitter, and a Deuterated Lanthanum a Alanine doped TriGlycine Sulphate detector at room temperature. The ATR sampling device worked with a diamond internal reflection element (IRE) in a single-reflection configuration. Spectra were recorded over the spectral range of $400-4000 \mathrm{~cm}^{-1}$ at a $4 \mathrm{~cm}^{-1}$ resolution, 24 scans. ATRFTIR analyses were performed for the identification of phosphate minerals for which we refer to Jastrzębski et al. (2011) and Monnier (2018).

Energy-dispersive X-ray spectroscopy analyses (EDS) of nodules B1A1 and B1B were performed to characterize the chemical composition of the studied nodules. A Quanta 200 SEM coupled with energy-dispersive X-ray spectroscopy (SEM/EDS) was used.

Trace elements were detected on $\mathrm{B} 1 \mathrm{~A} 1$ and $\mathrm{B} 1 \mathrm{~B}$ nodule samples and B1Ea, B1Ec, B1Ed, B1Ee, B1Wa, 
B1Wc sediment samples by plasma optical emission spectroscopy (ICP-OES) with an S10 autosampler. All data were generated using a PerkinElmer Optima 8000. The sample introduction system was as follows: nebulizer ( 1.0 mL/min flow); cyclonic spray chamber; 1 slot Torch. Argon was used as the nebulizer gas. The Multi-Element calibration standard 3 of Perkin Elmer was used. The samples were dissolved by the acid digestion method (EPA 3050B), using a microwave system (Titan MPS Perkin Elmer).

\section{RESULTS}

The XRD of nodules B1A1 and B1B indicated that quartz represents the only crystalline phase (Figs 3D, E). Further, XRD of B1X showed the presence of predominant quartz and minor amounts of clay minerals and feldspar as crystalline phases (Fig. 3F). The same analysis performed on sediments (samples B1Ee and B1Wa) revealed the presence of quartz, clay minerals and feldspar in all the collected samples. Calcite is absent or in traces (Figs 3G, 4A, C) in sediments from unit $B$ at the east side of the $\beta$ trench (unit $C$ of Mangano $\&$ Bonfiglio, 2005), while it is much more abundant (Figs 3H, 4D, E) in the western side of the same trench (layer B1). On this side, hydroxylapatite was also detected, likely resulting from bone fragmentation.

SEM analyses of $\mathrm{B} 1 \mathrm{~A}$ and $\mathrm{B} 1 \mathrm{~B}$ showed the presence of thin tabular microcrystals, up to about $5 \mathrm{~mm}$, incorporated in a colloform mass (Fig. 5). XRD analyses did not allow the mineralogical identification of the microcrystals. This is likely due to the abundant amorphous mass forming a very high background covering the microcrystals peaks (Fig. 3D).

\section{ANALYSES OF NODULES}
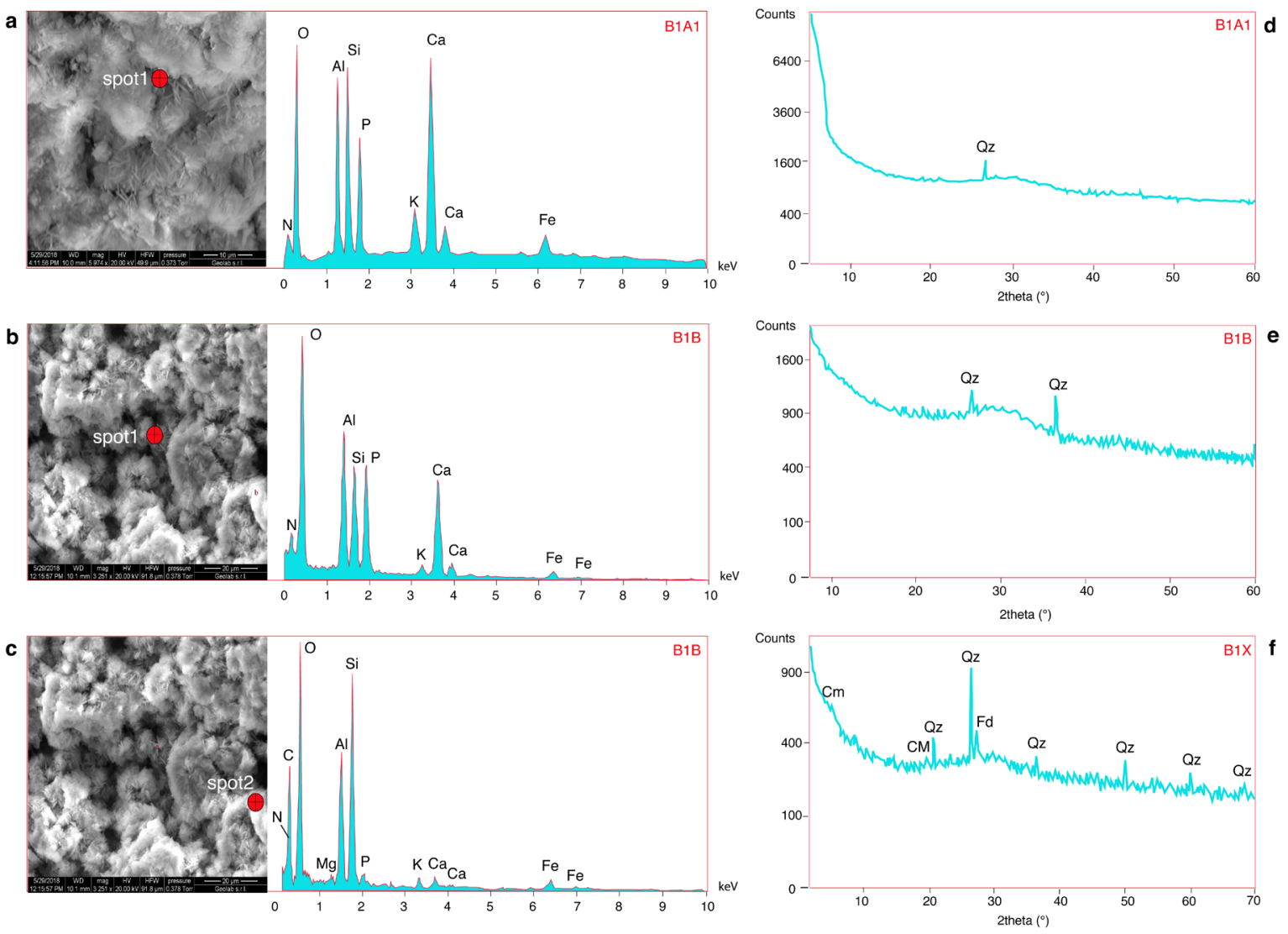

ANALYSES OF SEDIMENTS
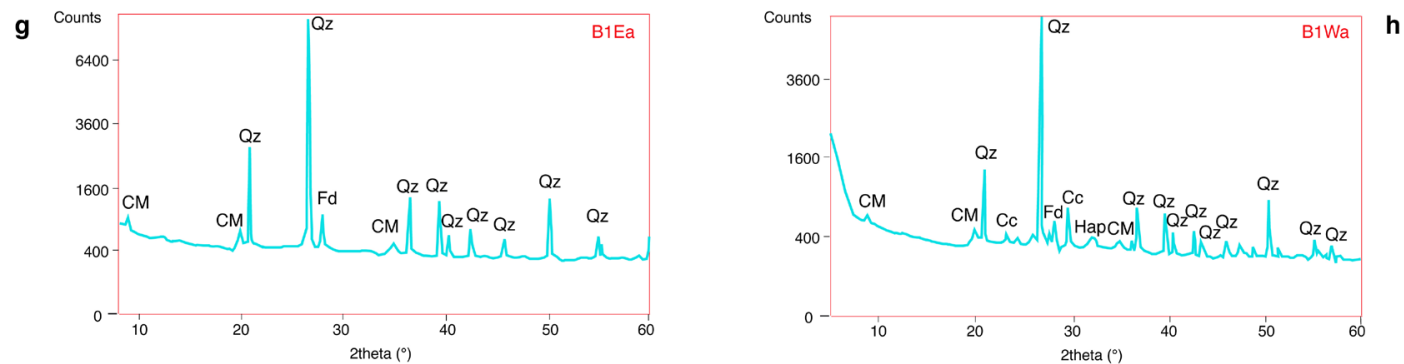

Fig. 3. EDS (a-c) with related SEM imagery, and XRD analyses of nodules B1A1, B1B, B1X (d-f) and sediment samples $\mathrm{B} 1 \mathrm{Ee}$ and B1Wa $(\mathrm{g}, \mathrm{h})$ from San Teodoro Cave. $(\mathrm{a}, \mathrm{b})$ EDS analyses of lamelliform crystals showing the major elements $\mathrm{P}$, $\mathrm{Al}, \mathrm{Ca}, \mathrm{Si} ; \mathrm{K}$ and $\mathrm{Fe}$ in smaller quantities. c) Spot on colloform mass showing major elements, $\mathrm{Al}$, Si, and $\mathrm{P}, \mathrm{Ca}, \mathrm{K}, \mathrm{Fe}, \mathrm{Mg}$ in smaller quantities; quite high amounts of $C$ probably come from embedded plant remain. $d$, e) XRD of samples B1A1 and B1B showing the predominance of amorphous substance and the main peaks of quartz. $f, g) X R D$ of B1X (f) and B1Ea (g) showing abundant quartz and a less quantity of feldspar and clay minerals. h) XRD of sample B1Wa showing abundant quartz and a less quantity of feldspar, calcite, clay minerals and hydroxylapatite. Qz=quartz, Fd=feldspar, Cc=calcite, Hap=hydroxylapatite, $\mathrm{CM}=$ clay minerals. Spots are indicated by red viewfinders. 

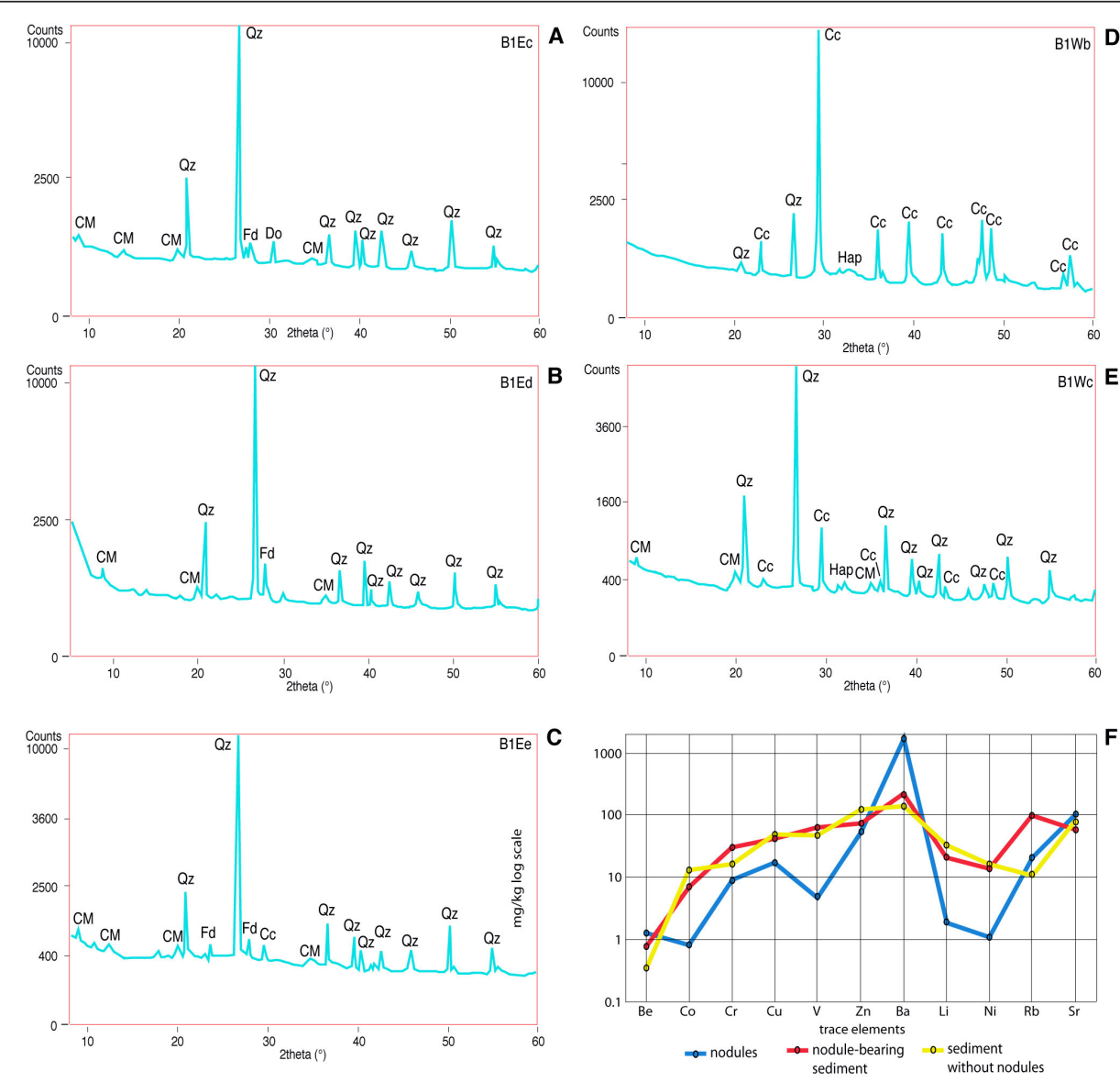

Fig. 4. Diffractometric analyses, XRD, A-E) and spider diagram $(F)$ showing the average of trace elements of samples from the Late Pleistocene site of San Teodoro (NE Sicily). Sediments (fraction lower than $2 \mathrm{~mm}$ ) collected at eastern (samples B1Ea, B1Ed and B1Ee) and western (samples B1Wb and B1Wc) parts of the $\beta$ trench of (Messina, NE Sicily). A, B) XRD of B1Ec and B1Ed (east part of the $\beta$ trench) showing the presence of abundant quartz and a lower amount of feldspar and clay minerals. C) XRD of B1Ee (east part of the $\beta$ trench) showing the same compounds as in $A$ and $B$ plus a scarce amount of calcite. D) XRD of B1Wb (west part of the $\beta$ trench) showing abundant calcite and subordinate quartz, rare clay minerals and hydroxylapatite. E) $X R D$ of B1Wc (west part of the $\beta$ trench) showing abundant quartz and a less quantity of feldspar, calcite, clay minerals and hydroxylapatite. $\mathrm{Qz}=$ quartz, $\mathrm{Fd}=$ feldspar, $\mathrm{Cc}=$ calcite, Hap = hydroxylapatite, $C M=$ clay minerals. $F)$ Spider diagram of nodules (B1A1, B1B), phosphatized sediments (B1Ea, B1Ec, B1Ed, and B1Ee) and non-phosphatized sediments (B1Wa, B1Wc).

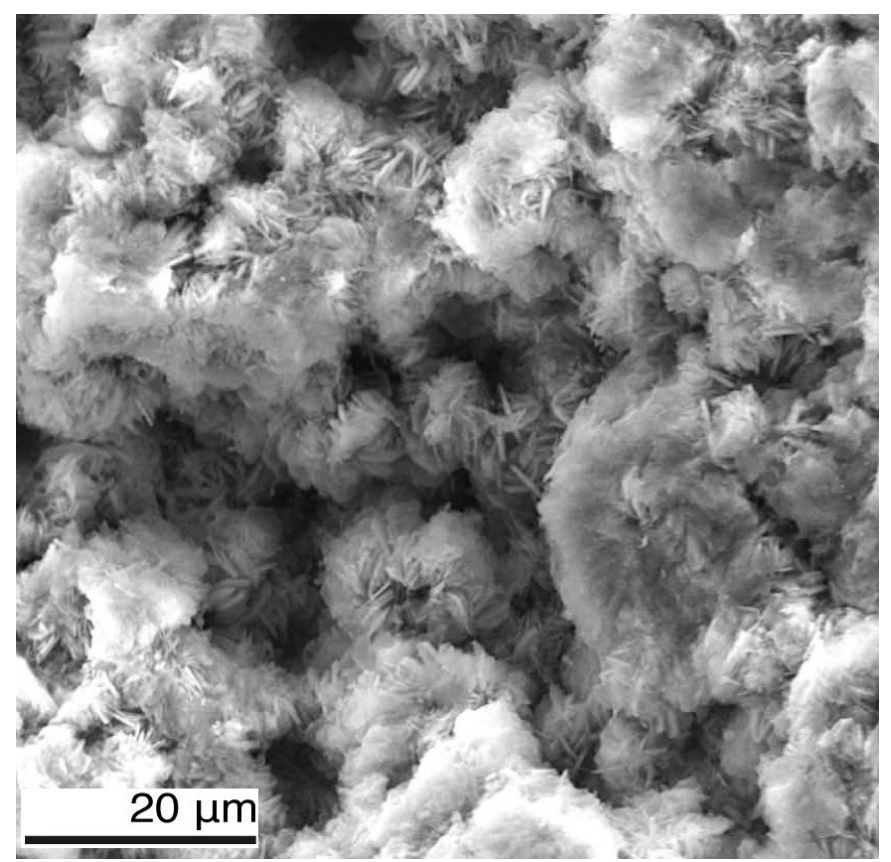

Fig. 5. SEM image of thin tabular crystals forming roughly subspherical aggregates from nodule B1B collected from the so-called unit $\mathrm{C}$ of Mangano and Bonfiglio (2005) at the east side of the $\beta$ trench of the Paleolithic site of San Teodoro, Sicily.
As a whole, the EDS of nodules (samples B1A1 and $\mathrm{B} 1 \mathrm{~B})$ allowed the detection of $\mathrm{Al}, \mathrm{Ca}, \mathrm{P}$, and a relevant amount of $\mathrm{Si}$, attributed to the presence of quartz and clay minerals, mainly indicated by the presence of $\mathrm{K}$ (Table 1 and Fig. 3A). This analysis also indicated that the thin tabular crystals revealed by SEM are made by elements such as $\mathrm{P}$ and Al. EDS also detected $\mathrm{Ca}$ and $\mathrm{Si}$ (Fig. 3B). The colloform mass resulted to be composed mainly by $\mathrm{Al}, \mathrm{Ca}, \mathrm{Si}$, and $\mathrm{P}$; secondarily by $\mathrm{Mg}, \mathrm{Fe}, \mathrm{K}$, and $\mathrm{N}$ (Fig. 3A, C, and Table 1). A relevant presence of $\mathrm{C}$ occurred only rarely (Table 1 ). This composition indicates the presence of clay minerals and amorphous phosphate in the colloform mass.

The elemental mapping of sample B1A1 showed a correlation between $\mathrm{P}, \mathrm{O}, \mathrm{Si}$, and $\mathrm{Al}$ (Fig. 6), suggesting a bond between these elements due to the interaction of phosphates with clay minerals. $\mathrm{Ca}$ is more evenly distributed within the sample.

The analyses of trace elements indicated that the Ba content (Table 2 and Fig. 4F) in nodules (1683 $\mathrm{mg} / \mathrm{kg}$ average value of samples $\mathrm{B} 1 \mathrm{~A} 1$ and $\mathrm{B} 1 \mathrm{~B})$ is much higher than that detected in the nodule-bearing sediment $(218 \mathrm{mg} / \mathrm{kg}$ average value of samples $\mathrm{B} 1 \mathrm{Ea}, \mathrm{B} 1 \mathrm{Ec}, \mathrm{B} 1 \mathrm{Ed}, \mathrm{B} 1 \mathrm{Ee})$ and the non-phosphatized 
Table 1. Percentages of major elements of nodules B1A1 and B1B from the $\beta$ trench of the Paleolithic site of San Teodoro, Sicily. bdl = below detection limit.

\begin{tabular}{|c|c|c|c|c|c|c|c|c|c|c|c|c|}
\hline Sample & Al & $\mathbf{P}$ & $\mathbf{K}$ & $\mathbf{N}$ & Mg & $\mathbf{C a}$ & $\mathbf{O}$ & $\mathbf{F e}$ & $\mathbf{S i}$ & $\mathbf{N a}$ & $\mathbf{s}$ & C \\
\hline B1A1 spot1 & 8.70 & 6.60 & 3.30 & 3.40 & bdl & 15.6 & 49.40 & 5.00 & 8.10 & bdl & bdl & bdl \\
\hline B1A1 spot2 & 9.20 & 6.40 & 1.10 & 2.10 & bdl & 6.70 & 64.90 & 5.00 & 7.10 & bdl & bdl & 0.30 \\
\hline B1A1 spot3 & 11.20 & 7.90 & 1.60 & 1.60 & 0.30 & 7.40 & 57.50 & 2.10 & 9.90 & 0.30 & 0.10 & 0.20 \\
\hline B1A1 spot4 & 9.90 & 7.40 & 2.40 & bdl & 0.50 & 12.00 & 49.00 & 9.80 & 8.30 & 0.70 & bdl & bdl \\
\hline B1A1 spot5 & 10.30 & 7.50 & 1.20 & 1.90 & 0.30 & 6.70 & 61.20 & 1.90 & 8.10 & 0.50 & 0.10 & 0.30 \\
\hline B1A1 average & 9.86 & 7.16 & 1.92 & 1.80 & 0.22 & 9.68 & 56.40 & 4.76 & 8.30 & 0.3 & 0.04 & 0.16 \\
\hline B1B spot1 & 11.80 & 8.60 & 1.90 & 2.00 & bdl & 9.30 & 53.90 & 2.30 & 10.30 & bdl & bdl & bdl \\
\hline B1B spot2 & 7.40 & 5.80 & 1.60 & 7.30 & 0.30 & 6.90 & 51.20 & 2.60 & 7.00 & 0.60 & bdl & 9.10 \\
\hline B1B spot3 & 11.60 & 8.80 & 2.70 & 2.60 & bdl & bdl & 46.10 & 4.20 & 11.00 & bdl & bdl & bdl \\
\hline B1B spot4 & 11.50 & 8.90 & 2.90 & 2.60 & bdl & 13.60 & 46.20 & 3.90 & 10.40 & bdl & bdl & bdl \\
\hline B1B average & 10.58 & 8.03 & 2.28 & 3.63 & 0.08 & 7.45 & 49.35 & 3.25 & 9.68 & 0.15 & bdl & 2.28 \\
\hline
\end{tabular}
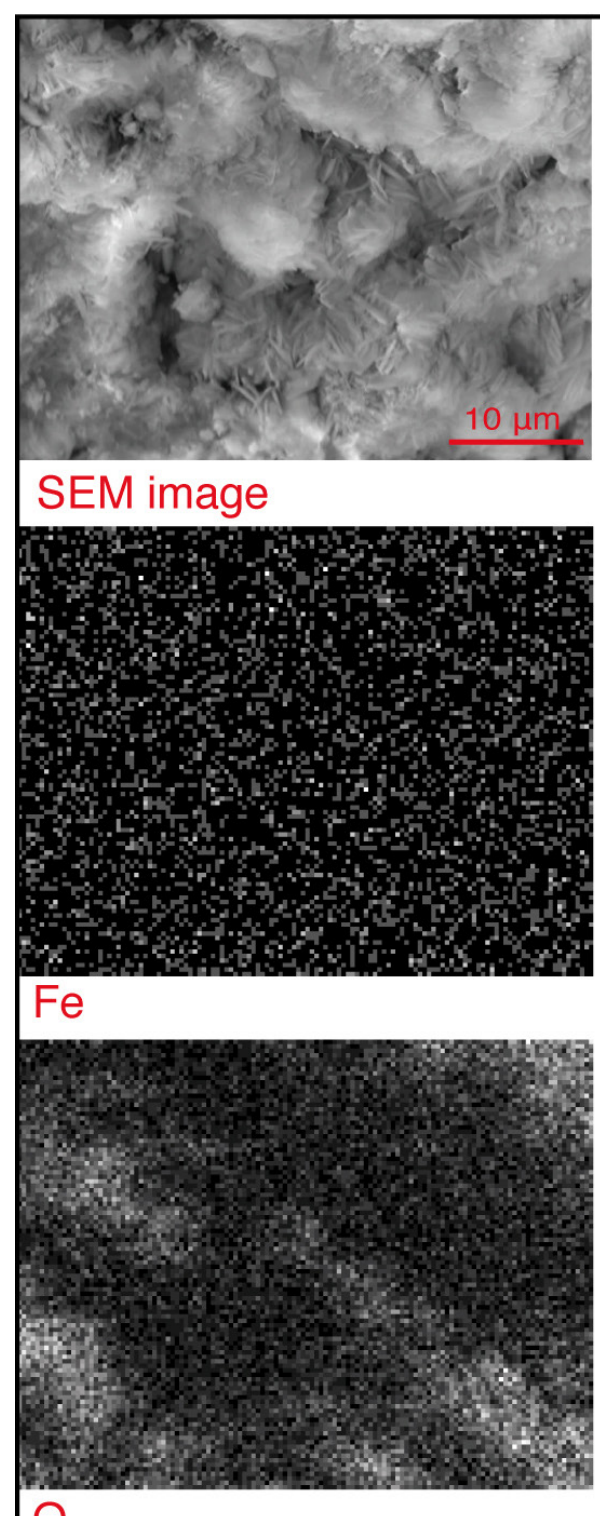

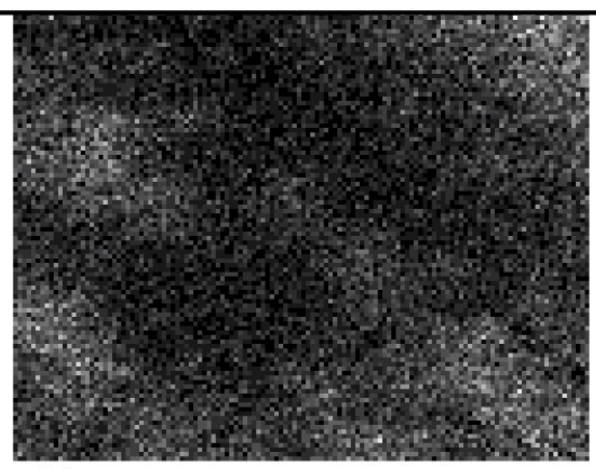

Al

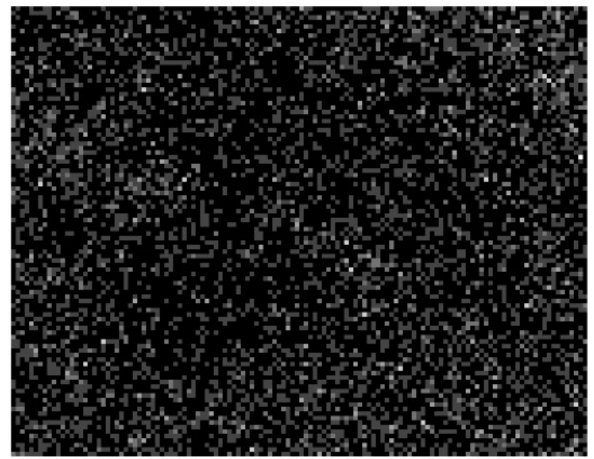

$\mathrm{K}$

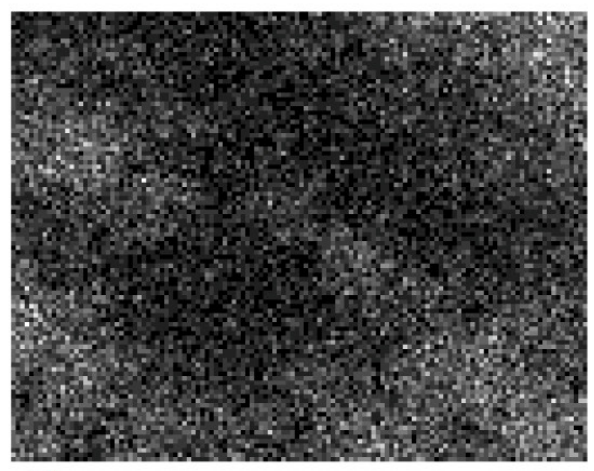

$\mathrm{P}$

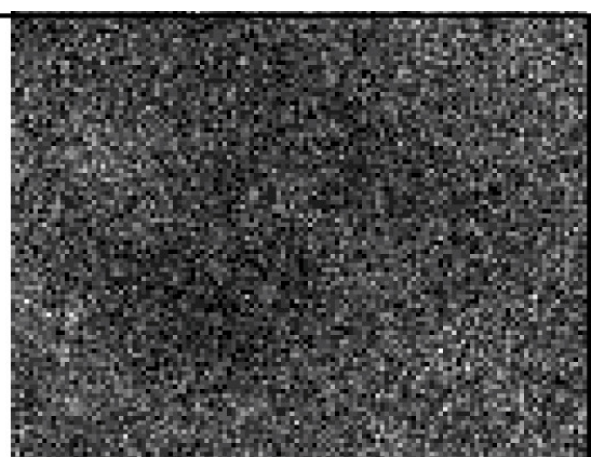

$\mathrm{Ca}$

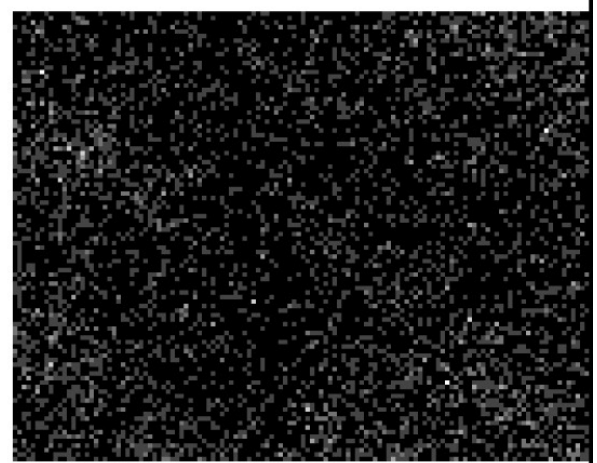

$\mathrm{Mg}$

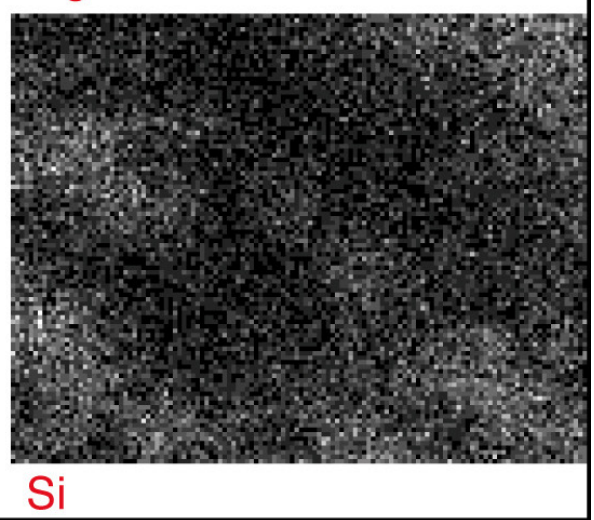

Fig. 6. Elemental mapping images showing the spatial distribution of various elements in the nodule B1A1.

sediment $(135 \mathrm{mg} / \mathrm{kg}$ average of samples B1Wa, B1Wc). Furthermore, these analyses also highlighted the much higher $\mathrm{Rb}$ content of the sediment at the east side of the $\beta$ trench, compared to that detected in the deposit at the west side of the trench $(98 \mathrm{mg} / \mathrm{kg}$ vs. $10 \mathrm{mg} / \mathrm{kg}$, see Table 2 and Fig. 4F).

ATR-FTIR analysis indicated the presence of variscite, a hydrated aluminum phosphate mineral, as the only phosphate crystalline phase present in the studied nodules (Fig. 7 and Table 3). The identification of variscite suggests that $\mathrm{Ca}$ and $\mathrm{Si}$ elements detected by EDS spots on the microcrystals observed in the nodules occur in the colloform mass. This inaccurate result was most likely due to the microscopic size of the crystals and the fact that they are almost totally incorporated into the colloform mass. 
Table 2. Minor elements $(\mathrm{mg} / \mathrm{kg})$ of nodules B1A1 and B1B and bulk samples B1Ea, B1Eb, B1Ec, B1Ed, B1Ee, B1Wa, and B1Wc from the $\beta$ trench of the Paleolithic site of San Teodoro, Sicily. bdl = below detection limit.

\begin{tabular}{|c|c|c|c|c|c|c|c|c|c|c|c|}
\hline Sample & $\mathrm{Be}$ & Co & $\mathbf{C r}$ & $\mathbf{C u}$ & $\mathbf{N i}$ & $\mathbf{V}$ & $\mathrm{Zn}$ & $\mathbf{B a}$ & $\mathbf{L i}$ & $\mathbf{R b}$ & $\mathbf{S r}$ \\
\hline $\mathrm{B} 1 \mathrm{~A} 1$ & 0.70 & 0.27 & 9.14 & 14.30 & 0.60 & 4.83 & 42.10 & 1895.00 & 2.70 & 12.10 & 126.00 \\
\hline B1B & 1.75 & 1.32 & 8.32 & 20.20 & 1.56 & 4.40 & 65.20 & 1472.00 & 0.949 & 28.50 & 74.50 \\
\hline B1A1-B1B average & 1.23 & 0.80 & 8.73 & 17.25 & 1.08 & 4.62 & 53.65 & 1683.00 & 1.82 & 20.30 & 100.25 \\
\hline $\mathrm{B} 1 \mathrm{Ea}$ & 0.98 & 3.62 & 28.18 & 47.03 & 11.69 & 61.38 & 61.38 & 284.84 & 16.84 & 118.19 & 61.54 \\
\hline $\mathrm{B} 1 \mathrm{Ec}$ & 0.90 & 6.25 & 27.17 & 44.56 & 9.03 & 75.02 & 75.02 & 231.49 & 13.08 & 108.75 & 53.32 \\
\hline $\mathrm{B} 1 \mathrm{Ed}$ & 1.14 & 4.44 & 40.10 & 45.81 & 17.89 & 84.30 & 81.32 & 244.15 & 21.35 & 122.77 & 48.35 \\
\hline $\mathrm{B} 1 \mathrm{Ee}$ & bdl & 13.45 & 20.69 & 29.67 & 15.13 & 26.10 & 70.24 & 109.80 & 30.80 & 42.98 & 67.66 \\
\hline B1Ea-B1Ee average & 0.75 & 6.94 & 29.04 & 41.77 & 13.43 & 61.70 & 71.99 & 217.57 & 20.52 & 98.17 & 57.72 \\
\hline $\mathrm{B} 1 \mathrm{Wa}$ & bdl & 14.02 & 31.79 & 57.68 & 24.51 & 46.38 & 146.04 & 136.45 & 59.81 & 9.62 & 70.42 \\
\hline $\mathrm{B} 1 \mathrm{Wc}$ & 0.67 & 11.66 & 1.05 & 36.82 & 7.21 & 47.50 & 97.16 & 134.78 & 3.40 & 11.36 & 82.79 \\
\hline B1Wa-B1Wc average & 0.34 & 12.84 & 16.42 & 47.25 & 15.86 & 46.94 & 121.60 & 135.62 & 31.61 & 10.49 & 76.61 \\
\hline
\end{tabular}

Table 3. Assignment of the ATR- FTIR vibration bands of nodules B1A1 and B1B.

\begin{tabular}{|c|c|c|}
\hline \multirow{2}{*}{ Functional group } & \multicolumn{2}{|c|}{ Wavenumber $\left(\mathrm{cm}^{-1}\right)$} \\
\hline & Sample B1A1 & Sample B1B \\
\hline $\mathrm{PO}_{4}$ Symmetric bending vibration & $415 \mathrm{w}$ & $416 w$ \\
\hline $\mathrm{v} 2 \mathrm{PO}_{4}$ & $437 \mathrm{w}$ & $433 w$ \\
\hline v2 phosphate bending vibrations & $454 w$ & $457 \mathrm{vw}$ \\
\hline $\mathrm{PO}_{4} / \gamma \mathrm{Fe}_{2} \mathrm{O}_{3}$ & $471 \mathrm{vw}$ & $478 \mathrm{vw}$ \\
\hline apatitic calcium phosphate & - & $500 \mathrm{vw}$ \\
\hline $\mathrm{O}-\mathrm{P}-\mathrm{O}$ & $547 \mathrm{w}$ & $542 \mathrm{~m}$ \\
\hline $\mathrm{PO}_{4}$ & $556 w$ & - \\
\hline$\left(\mathrm{Al}_{2} \mathrm{OH}\right)$ vibrations & $587 \mathrm{w}$ & - \\
\hline $\mathrm{OH}$ (librational) & - & $639 \mathrm{vw}$ \\
\hline$\gamma \mathrm{Fe}_{2} \mathrm{O}_{3}$ & $691 \mathrm{vw}$ & $691 \mathrm{vw}$ \\
\hline calcium carbonate & - & $734 \mathrm{vw}$ \\
\hline $\mathrm{PO}_{4}$ & $1001 \mathrm{vs}$ & $1004 \mathrm{vs}$ \\
\hline $\mathrm{CO}_{3}$ & - & $1530 \mathrm{w}$ \\
\hline $\mathrm{H}_{2} \mathrm{O}$ & $1640 \mathrm{~m}$ & $1641 \mathrm{~m}$ \\
\hline OH hydrogen bonded (of Al-OH stretching vibrations) & $3351 \mathrm{sh}$ & 3350 sh \\
\hline
\end{tabular}
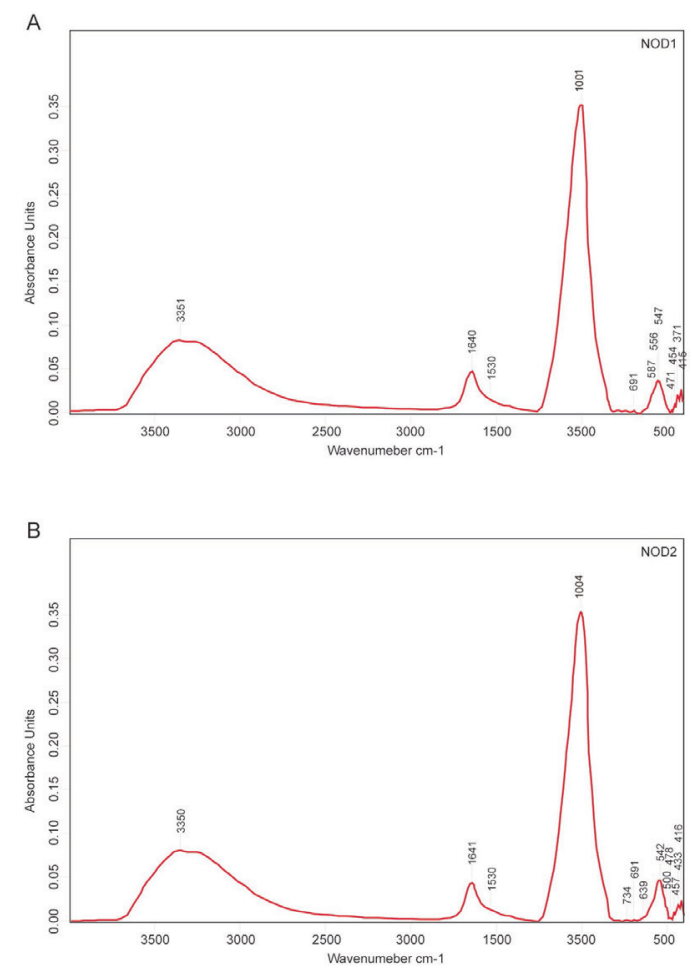

Fig. 7. ATR-FTIR spectra of nodules B1A1 (A) and B1B (B).

\section{DISCUSSION}

The geochemical and mineralogical analyses performed on clayey sediments from the $\beta$ trench at the Paleolithic site of the San Teodoro Cave allowed the detection of phosphatic nodules in the east side of the trench, in the sterile part called unit $\mathrm{C}$ by Mangano and Bonfiglio (2005) and by the same authors interpreted as the result of erosion and depositional processes in lacustrine conditions.

From the macroscopic point of view, nodules comparable to those studied at San Teodoro were found in Butler Cave (USA) by White (1982) and in Măgurici Cave (Romania) by Onac and Vereş (2003). However, at these sites the guano is in contact with the clayey deposits of the caves.

Phosphates are common in caves (Onac, 2019), where they are produced by the reaction of guano (naturally rich in P) (Karkanas et al., 2000 and references within; McFarlane \& Lundberg, 2018; Queffelec et al., 2018) with clay, bones and carbonates present in the sediments. Fresh guano contains 10$12 \%$ of $\mathrm{P}_{2} \mathrm{O}_{5}$, but this percentage increases up to 20 $32 \%$ in leached guano. The mineralogy of guano may 
vary largely, though the decomposed guano generally consists of calcium phosphates. The mineralogical composition of guano-derived phosphate deposits depends on the nature of the host rock. Where the host rock is calcareous, the phosphate mineral is apatite; where it is a silicate, the phosphate minerals are aluminum or aluminum-iron phosphates (McKelvey, 1967). The decomposition of guano produces fluids and gases, lowering the $\mathrm{pH}$ values of the sediments down to 6 , with an increase in acidity with age and depth (Pogson et al., 2014; Audra et al., 2019). In these $\mathrm{pH}$ conditions carbonate elements and bones undergo dissolution (e.g., Kowalski, 1995; Quattropani et al., 1999; Stiner et al., 2001, Kourampas et al., 2015), producing sediment enrichment in $\mathrm{P}$ and $\mathrm{Ca}$. Studies conducted in the laboratory (Boblitt et al., 2018) and in situ (Mcadams et al., 2021) on the degradation of bones due to the acidification produced by bat guano, showed that bone phosphates dissolved quite easily in cave sites. After "digestion" by acidic guano leachates, the most resistant minerals, such as quartz, muscovite and feldspars, remain (Audra et al., 2021). In the same conditions, the leaching of clays produces Al (Merino et al., 2019). The interaction of carbonates and clay minerals with the $\mathrm{P}$ produced by the guano decomposition facilitates the precipitation of phosphate minerals (White, 1982; Hill \& Forti, 1997). The formation of these minerals needs a sufficient presence of water (McFarlane \& Lundberg, 2018), and cannot occur in a very dry area (Karkanas et al., 2000). The EDS analyses of the studied nodules delineated a chemical environment characterized by $\mathrm{Al}, \mathrm{Si}, \mathrm{Ca}$, and $\mathrm{P}$, suggesting that similar geobiochemical processes drove their formation. The map of the elements suggests a close interaction between phosphates and clay minerals. The guano deposit, most likely, triggered the processes that produced bone and carbonate dissolution, and sediment phosphatizing at the east part of the $\beta$ trench. Several phosphate minerals may form in cave or soil environments (e.g., Karkanas \& Goldberg, 2010). In acidic environments, when bones, guano and clays represent a consistent part of the deposits, crandallite, montgomeryite, taranakite, amorphous phosphates, and variscite can be formed (Goldberg \& Nathan, 1975; Nriagu, 1976; Martini \& Kavalieris, 1978; Weiner et al., 1993; Hill and Forti, 1997; Quattropani et al., 1999; Stiner et al., 2001; Weiner et al., 2002; Berna et al., 2004; Onac et al., 2004, 2009; Karkanas, 2010; Onac, 2012; Shahack-Gross et al., 2004; Giurgiu et al., 2013; Giurgiu \& Tămaş, 2013; Pogson et al., 2014; Wurster et al., 2015; Miller et al., 2016; McFarlane \& Lundberg, 2018; Audra et al., 2019, 2021). The presence of these minerals in sterile archaeological sediments, therefore, indicates that a rich bone fossil compound originally occurred (Goldberg \& Nathan, 1975; Quattropani et al., 1999; Karkanas et al., 2000; 2010; Shahack-Gross et al., 2004). Studies on the stability of bones exposed to different $\mathrm{pH}$ levels indicate that they are stable in samples with a $\mathrm{pH}$ level above 8.1, undergo recrystallization between the $\mathrm{pH}$ of 8.1 and 7.4 , and rapidly dissolve with $\mathrm{pH}$ values below 7 (Hedges \& Millard, 1995; Berna et al., 2004; Karkanas, 2010; Trovillo, 2015). The XRD analyses performed on the studied phosphatic nodules did not allow the mineralogical identification of the microcrystals detected by SEM observations, very likely because of the abundant amorphous mass that embeds them drowning their signals out. However, the ATR-FTIR analysis, based on Jastrzębski et al. (2011) and Monnier (2018), points to the presence of variscite. Even the thin tabular habitus of the detected microcrystals, their very small size and mode of aggregation observed in a studied nodule are compatible with those of certain variscite (compare Fig. 4 with Fig. 4f of Drüppel et al., 2007). The phosphatic colloform, an amorphous mass where the microcrystals are scattered is prevalently made by $\mathrm{Al}$, $\mathrm{Ca}, \mathrm{Si}$, and $\mathrm{P}$. The elemental mapping indicated that $\mathrm{Al}$, $\mathrm{Ca}$ and $\mathrm{P}$, are bonded thus suggesting that amorphous phosphate is present. Amorphous phosphates are a component in caves having been identified in many sites (e.g., White, 1982; Karkanas, 2000; Giurgiu \& Tămaş, 2013; Mcadams et al., 2021). The XRD analyses of the phosphatized and nonphosphatized bone-bearing sediments, in the east and west sides of the beta trench, respectively, support the hypothesis of the formation of an acidic environment and the resulting dissolution of bones and carbonate remains in the east part of the San Teodoro $\beta$ trench. These analyses highlighted the lack of hydroxylapatite and the lack/very low amount of calcite in the phosphatized sediments, while allowed the detection of these minerals in the fossiliferous deposits at the west side of the same trench. Also, this explains the paleontological sterility of unit $\mathrm{C}$ of Mangano and Bonfiglio (2005) and indicates that this deposit should be regarded as a phosphatized part of layer B1 rather than a younger unit separated from the unit B by an erosion surface. Phosphatization originated from the enrichment in phosphorus produced by a large amount of guano, and the dissolution of bones caused by acidification occurred only at the east side of the inner part of the study site. As a consequence, the west side of the $\beta$ trench still bears fossil bones, representing the Pleistocene San Teodoro/Pianetti faunal complex, while at the east side bone remains did not preserve. This kind of diagenesis, which can generate paleontological sterility, commonly occurs in cave sites rich in guano (Shahack-Gross et al., 2004; Karkanas, 2010). Based on cross-checking of data on the bone distribution and their degree of alteration, and on the spatial detection of mineral phases detected by portable FTIR at the Kebara Cave (Israel), Weiner et al. (1993) recognized those sediments that had lost their osteological content. Similarly, to the case of the study site, at the Elands Bay Cave, in South Africa, Miller et al. (2016) identified areas where the fossils had been dissolved and microcrystalline clay-rich nodules with variscite (detected by ATR-FTIR and XRD) had formed. The exclusive presence of phosphate nodules in the eastern part of the study cave is likely due to the shape of its ceiling. In the central part, over the 
western side of the $\beta$ trench, the ceiling forms a large vault frequented by owls, as evidenced today by the numerous wads, therefore an unsuitable place for bats. Differently, the ceiling has narrow slits very suitable for bats over the eastern part of the same trench, where the highest percentage of bat fossils (about $35 \%$ of micromammals found) were recovered in the areas near the east wall not subject to the phosphating. (Bonfiglio et al., 2008). Therefore, it is reasonable to suppose that bats produced considerable quantities of excrement only at one side of the cave. Further, the carbonate boulder B2, isolating the east from the west side of the innermost part of the cave, acted as a container and confined the guano and the products of its decomposition to the eastern cave wall. Nodules, therefore, originated after the formation of B2, which presumably occurred during the LGM (Vita, 2021), likely in a period in which humans were not present or occasionally inhabited the cave, as bats flee the human presence (Rosina, 2006; Karkanas, 2017; Mcadams et al., 2019). The analysis of trace elements provide further evidence that the formation of phosphate nodules is the result of interactions between sediments and the biological activity of bats. This interaction veiled the original nature of the sediment. The barium content found in the studied nodules, so much higher than in the nodule-bearing sediment and in the non-phosphatized sediment on the west side of the cave, is due to the rich bacterial community that lived in the guano (see De Leon et al., 2018). The degradation of guano allows the proliferation of microorganisms in the soil, triggering the mobilization and concentration of barium (Sanchez-Moral et al., 2004; Sauro et al., 2018). For example, the bacterium Myxococcus xanthus, ubiquitous in soils (Muñoz-Dorado et al., 2016), concentrates barium in the form of barite (GonzálezMuñoz et al., 2003). Even in seawater, barium bioaccumulation is found in amorphous phosphorus deposits when a high amount of organic matter undergoes bacterial degradation (Martinez Ruiz et al. 2018). Our study also indicated that other elements, such as $\mathrm{V}, \mathrm{Cr}, \mathrm{Cu}, \mathrm{Zn}, \mathrm{Ni}$, and $\mathrm{Co}$, are much more abundant in the sediment and are depleted in the nodules. These chemical differences between sediments and nodules can be explained by the bonds that some elements form with organic matter. Siy (1988) showed that phosphate nodules have lower concentrations of organic matter than host rocks; consequently, the transition metals associated with the organic material are also depleted in the nodules. Also, rubidium is much more abundant in the phosphatized than in the non-phosphatized sediments studied. This is why this element is generally abundant in the guano, as indicated by Miko et al. (2001) for cave sediments in Croatia.

All these geochemical and (paleo)biological considerations strongly indicate that a new paleoenvironmental reconstruction, different from that hypothesized by previous papers (Mangano \& Bonfiglio, 2005; Mangano et al., 2005, 2020), should be invoked for the formation of the phosphate nodules in the innermost part of the San Teodoro cave. At this site, therefore, the identification of a further unit $\mathrm{C}$ resulted from erosion processes and subsequent deposition of lacustrine sediments should be discarded. Sediments of the so-called unit C should instead be regarded as belonging to unit B, particularly to layer B1, with which unit C should be identified.

\section{CONCLUSION}

The review of paleoenvironmental interpretations of problematic settings like those in paleoarchaeological cave sites using geo(bio)chemical tools can be of great benefit. The study of phosphate nodules from the sediments of the Late Pleistocene site of San Teodoro showed that geochemical processes could be strictly linked to biological processes, specifically those resulting from the bat life history, and can remarkably influence the taphonomy of some cave deposits. The understanding of this relationship and the use of geochemical analyses integrated with (paleo)biological evidence are of great help in solving problematic depositional settings. The original sediment was modified for the dissolution of carbonates. The subsequent interaction between clay minerals and phosphates produced heterogeneous nodules with minerals and amorphous substance. Only minerals that are not subject to acid attacks, such as quartz and feldspars, remained to testify to the original nature of the sediment. The high content of barium in the phosphate nodules and of rubidium in the phosphatized sediments is indicative of how strong is the interaction between biology and geochemistry in soil and cave environments. Both elements are significant markers of the origin of phosphating in cave sites and are important to reconstruct taphonomical processes. In particular, rubidium indicates the role of guano in phosphatizing sediments.

Thanks to paleobiological and geochemical approaches, a correlation between stratigraphical layers showing different lithological characters was made possible and new paleoenvironmental reconstructions were achieved even in absence of paleontological remains. Made sterile by phosphatizing, the so-called unit $\mathrm{C}$ in the study cave resulted to be a phosphatized part of the large mammals bearing inside layer B1 rather than a younger deposit formed in lacustrine conditions. Phosphatization originated after the B2 formation, which occurred during the LGM. Our results, therefore, discard the hypothesis of the excavation created by erosion and of precipitation of nodules in super-saturated sediments at the study site.

\section{ACKNOWLEDGEMENTS}

We are grateful to Soprintendenza Beni Culturali ed Ambientali, and Parco Archeologico di Tindari (Messina, Italy), who gave permission to sample the site of San Teodoro Cave. Francesco Giordano (Istituto per lo Studio dei Materiali Nanostrutturati, CNR, Palermo, Italy) is acknowledged for XRD measurements. Thanks are due to Vitor Gaspar 
(Laboratory of Physics and Chemistry and X-ray of Polytechnic Institute of Tomar, Portugal) for FTIR analyses. We thank Laurent Bruxelles (Institut National de Recherches Archéologiques Préventives, CNRS, Paris, France) and anonymous reviewers for the remarkable contribution to this paper.

Authorship statement: GV designed this study, acquired most data and wrote an early draft. VG and LS participated in the design. VG, MPV, and GV wrote the submitted manuscript. VG prepared figures and tables. MAV did the ICP-OES measurements. RG, GV, and AM performed SEM analyses, whereas GV and VLP collected the XRD data. PR is credited for the FTIR investigations. LB, VG, GV, MPV, and LS contributed to sampling. RG, GV, and MAV interpreted geochemical results. All authors discussed the results and contributed to the final manuscript.

\section{REFERENCES}

Anca, F., 1860. Note sur deux nouvelles grottes ossiferes decouvertes en Sicile en 1859. Bulletin de la Societé Géologique de France, 17, 684-695.

Antonioli, F., Lo Presti, V., Gasparo Morticelli, M., Bonfiglio, L., Mannino, M., Palombo, M.R., Sannino, G., Ferranti, L., Furlani, S., Lambeck, K., Canese, S.P., Catalano, R., Chiocci, F.L., Mangano, G., Schicchitano, G., Tonielli, R., 2014. Timing of emergence of the Europe Sicily bridge (40-17 cal ka BP) and its application for the spread of modern humans. In: Harf, J., Bailey, G., Lüth, F. (Eds.), Geology and archaeology: Submerged landscapes of the continental shelf. Geological Society, London, Special Publication, 411, 111-144.

https://doi.org/10.1144/SP411.1

Audra, P., De Waele, J., Bentaleb, I., Chroňáková, A., Krištůfek. V., D’Angeli, I. M., Carbone, C., Madonia, G., Vattano, V., Scopelliti, G., Cailhol, D., Vanara, N., Temovski, M., Bigot, J., Nobécourt, J., Galli, E., Rull, F., Sanz-Arranz, A., 2019. Guano-related phosphaterich minerals in European caves. International Journal of Speleology, 48(1), 75-105.

https://doi.org/10.5038/1827-806X.48.1.2252

Audra, P, Heresanu, V., Barriquand, L., Boutchich, M.E.K., Jaillet, S., Pons-Branchu E., Pavel Bosák P., Cheng, Hai, Edwards, R.L., Renda, M., 2021. Bat guano minerals and mineralization processes in Chameau Cave, Eastern Morocco. International Journal of Speleology, 50(1), 91-109. https://doi.org/10.5038/1827-806X.50.1.2374

Drüppel, K., Hösch, A., Franz, G., 2007. The system $\mathrm{Al}_{2} \mathrm{O}_{3}-$ $\mathrm{P}_{2} \mathrm{O}_{5}-\mathrm{H}_{2} \mathrm{O}$ at temperatures below $200^{\circ} \mathrm{C}$ : Experimental data on the stability of variscite and metavariscite $\mathrm{AlPO}_{4} \cdot 2 \mathrm{H}_{2} \mathrm{O}$. American Mineralogist, 92, 1695-1703.

Berna, F., Matthews, A., Weiner, S., 2004. Solubilities of bone mineral from archaeological sites: The recrystallization window. Journal of Archaeological Science, 31, 867-882.

https://doi.org/10.1016/j.jas.2003.12.003

Boblitt, C.M., Plotnick, R.E., Kenig, F., Meyer-Dombard, D., 2018. Determining taphonomic controls and rates of decay in cave environments using Microcosms. Palaios, 33, 141-153.

https://doi.org/10.2110/palo.2017.047

Bonfiglio, L., Mangano, G., Marra, A.C., Masini, F., 2001. A new late Pleistocene vertebrate faunal complex from Sicily (S. Teodoro Cave, North Eastern Sicily, Italy).
Bollettino della Società Paleontologica Italiana, 40, 149-158.

Bonfiglio, L., Esu, D., Mangano, G., Masini, F., Petruso, D., Soligo, M., Tuccimei, P., 2008. The Late Pleistocene vertebrate bearing deposits at San Teodoro Cave (North-Eastern Sicily): preliminary data on faunal diversification and chronology. Quaternary International, 190, 26-37. https://doi.org/10.1016/j.quaint.2007.10.019

Brochier, J.É., 1993. Cayönü Tepesi. Domestication, rhythmes et environment au PPNB. Paléorient, 19(2), 39-49. https://doi.org/10.3406/paleo.1993.4595

D’Amore, G., Di Marco, S., Tartarelli, G., Bigazzi, R., Sineo, L., 2009. Late Pleistocene human evolution in Sicily: comparative morphometric analysis of Grotta di San Teodoro craniofacial remains. Journal of Human Evolution, 56, 537-550. https://doi.org/10.1016/j.jhevol.2009.02.002

De Leon, M.P., Montecillo, A.D., Pinili, D.S., Siringan, M.A.T., Park, D.-S., 2018. Bacterial diversity of bat guano from Cabalyorisa Cave, Mabini, Pangasinan, Philippines: A first report on the metagenome of Philippine bat guano. PLoS ONE, 13(7), 1-17. https://doi.org/10.1371/journal.pone.0200095

Esu, D., Mangano, G., Bonfiglio, L., 2007. The molluscan fauna from the upper Pleistocene vertebrate-bearing deposits of S. Teodoro Cave (north-eastern Sicily). Rivista Italiana di Paleontologia e Stratigrafia, 113, 127-138.

Farrand, W.R., 2001. Sediments and stratigraphy in rockshelters and caves: A personal perspective on principles and pragmatics. Geoarchaeology, 16(5), 537-557. https://doi.org/10.1002/gea.1004

Fiore, S., Laviano, R., 1991. Brushite, hydroxylapatite, and taranakite from Apulian caves (southern Italy): New mineralogical data. American Mineralogist, 76, 1722-1727.

Garilli, V., Vita, G., La Parola, V., Pinto-Vraca, M., Giarrusso, R., Rosina, P., Bonfiglio, L., Sineo, L., 2020a. First evidence of Pleistocene ochre production from bacteriogenic iron oxides. A case study of the Upper Paleolithic site at the San Teodoro Cave (Sicily, Italy). Journal of Archaeological Science, 123, 105221. https://doi.org/10.1016/j.jas.2020.105221

Garilli, V., Vita, G., Bonfiglio, L., Mulone, A., Sineo, L., 2020b. From sepulchre to butchery-cooking: Facies analysis, taphonomy and stratigraphy of the Upper Paleolithic post burial layer from the San Teodoro Cave (NE Sicily) reveal change in the use of the site. Journal of Archaeological Science: Reports, 30, 102191. https://doi.org/10.1016/j.jas.2020.105221

Giunta, G., Giorgianni, A, Carbone, S., Di Stefano, A., Russo, S., Puglisi, D., Orioli, S., Li Bianchi, B., Oliveri, E., Oriti, M., Profeta, R., 2013. Carta Geologica d'Italia alla scala 1:50.000. Foglio 598 Sant'Agata di Militello. Progetto CARG, ISPRA. Servizio Geologico d'Italia, Rome.

Giurgiu, A., Tămaş, T., 2013. Mineralogical data on bat guano deposits from three Romanian caves. Studia UBB Geologia, 58(2), 13-18.

https://doi.org/10.5038/1937-8602.58.2.2

Giurgiu, A.M., Onac, B.P., Tămaş, T., Fornós, J.J., 2013. Evolution of guano under different environmental conditions: a mineralogical approach. Proceedings of the 16th International Congress of Speleology, Brno, Czech Republic, p. 483-485.

Goldberg, P., Nathan, Y., 1975. The phosphate mineralogy of et-Tabun cave, Mount Carmel, Israel. Mineralogical Magazine, 40, 253-258. 
https://doi.org/10.1180/minmag.1975.040.311.06

González-Muñoz, M.T., Fernández-Luque, B., MartínezRuiz, F., Chekroun, K.B., Arias, J.M., RodríguezGallego, M., Martínez-Cañamero, M., de Linares, C., Paytan, A., 2003. Precipitation of barite by Myxococcus xanthus: Possible implications for the biogeochemical cycle of barium. Applied and Environmental Microbiology, 69, 9, 5722-5725. https://doi.org/10.1128/AEM.69.9.5722-5725.2003

Graziosi, P., 1947. Gli uomini della grotta di S. Teodoro (Messina). Rivista di Scienze Preistoriche 2, 123-224.

Hedges, RE.M, Millard, A.R., 1995. Bones and groundwater: towards the modelling of diagenetic processes. Journal of Archaeological Science, 22, 155-164. https://doi.org/10.1006/jasc. 1995.0017

Hill, C.A., Forti, P., 1997. Cave minerals of the world (2nd Ed.). National Speleological Society, Huntsville, Alabama, 464 p.

Jastrzębski, W., Sitarz, M., Rokita, M., Bułat, K., 2011. Infrared spectroscopy of different phosphates structures. Spectrochimica Acta Part A: Molecular and Biomolecular Spectroscopy, 79, 722-727. https://doi.org/10.1016/j.saa.2010.08.044

Karkanas, P., Kyparissi-Apostolika, N., Bar-Yosef, O., Weiner, S., 1999. Mineral assemblages in Theopetra, Greece: A framework for understanding diagenesis in a prehistoric cave. Journal of Archaeological Science, 26, 1171-1180.

https://doi.org/10.1006/jasc.1998.0354

Karkanas, P., Bar-Yosef, O., Goldberg, P, Weiner, S., 2000. Diagenesis in prehistoric caves: the use of minerals that form in situ to assess the completeness of the archaeological record. Journal of Archaeological Science, 27, 915-929.

https://doi.org/10.1006/jasc. 1999.0506

Karkanas, P., 2010. Preservation of anthropogenic materials under different geochemical processes: a mineralogical approach. Quaternary International, 214(1-2), 63-69. https://doi.org/10.1016/j.quaint.2009.10.017

Karkanas, P., 2017. Guano. In: Nicosia, C., Stoops, G. (Eds.), Archaeological soil and sediment micromorphology. Wiley, Hoboken, p. 83-89.

Karkanas, P., Goldberg, P., 2010. Phosphatic Features: In: Stoops, G., Marcelino, V., Mees, F. (Eds.), Interpretation of micromorphological features of soils and regoliths. p. 521-540.

Kourampas, N., Shipton, C., Mills, W., Tibesasa, R., Horton, H., Horton, M., Prendergast, M., Crowther, A., Douka, K., Faulkner, P., Picornell, L., Boivin, N., 2015. Late Quaternary speleogenesis and landscape evolution in a tropical carbonate island: Pango la Kuumbi (Kuumbi Cave), Zanzibar. International Journal of Speleology, 44(3), 293-314. http://dx.doi.org/10.5038/1827-806X.44.3.7

Kowalski, K., 1995. Taphonomy of bats (Chiroptera). Geobios, 18, 251-256. https://doi.org/10.1016/S0016-6995(95)80172-3

Lentini, F., Catalano, S., Carbone, S., 2000. Carta geologica della Provincia di Messina (Sicilia nordorientale). Note illustrative, SELCA, Firenze.

Mangano, G., Bonfiglio, L., 2005. New stratigraphic and taphonomic data from the late Pleistocene deposits of the San Teodoro Cave (North-Eastern Sicily, Italy). Annali dell'Università degli Studi di Ferrara, Museologia Scientifica e Naturalistica. Volume Speciale, p. 89-97. http://dx.doi.org/10.15160/1824-2707/358

Mangano, G., Bonfiglio, L., Petruso, D., 2005. Excavations of 2003 at the S. Teodoro cave (North-Eastern Sicily, Italy): preliminary faunistic and stratigraphic data.
Geo.Alp, 2, 71-76.

Mangano, G., 2011. An exclusively hyena-collected bone assemblage in the Late Pleistocene of Sicily: taphonomy and stratigraphic context of the large mammal remains from San Teodoro Cave (North-Eastern Sicily, Italy). Journal of Archaeological Science, 38, 3584-3595. https://doi.org/10.1016/j.jas.2011.08.029

Mangano, G., Insacco, G., Bonfiglio, L., Mazza, P.P., 2020. New finds from San Teodoro Cave: an updating of the Middle Pleistocene fossil record from Acquedolci (north-eastern Sicily). Palaeobiodiversity and Palaeoenvironments, 100, 1965-1076. https://doi.org/10.1007/s12549-020-00430-7

Mannino, M.A., Di Salvo, R., Schimmenti, V., Di Patti, C., Incarbona, A., Sineo, L., Richards, M.P., 2011. Upper Paleolithic hunter-gatherer subsistence in Mediterranean coastal environments: an isotopic study of the diets of the earliest directly-dated humans from Sicily. Journal of Archaeological Science, 38, 3094-3100. https://doi.org/10.1016/j.jas.2011.07.009

Martini, J., Kavalieris, I., 1978. Mineralogy of the Transvaal caves. South African Journal of Geology, 81(1), 47-54.

https://hdl.handle.net/10520/AJA10120750_2836

Matthews, T., Marean, C.W., Cleghorn, N., 2019. Past and present distributions and community evolution of Muridae and Soricidae from MIS 9 to MIS 1 on the edge of the Palaeo-Agulhas Plain (south coast, South Africa). Quaternary Science Reviews, 235, 105774.

https://doi.org/10.1016/j.quascirev.2019.05.026

Maviglia, C., 1941. Scheletri umani del Paleolitico Superiore rinvenuti nella Grotta di S. Teodoro (Messina). Archivio per l'Antropologia e l'Etnologia, 70, 94-104.

Mcadams, C., Morley, M.W., Fu, X., Kandyba, A., Derevianko, A., Nguyen, D., Doi, N., Roberts, R.G., 2019. The Pleistocene geoarchaeology and geochronology of Con Moong Cave, North Vietnam: Site formation processes and hominin activity in the humid tropics. Geoarchaeology, 35, 72-97.

https://doi.org/10.1002/gea.21758

Mcadams, C., Morley, M., Roberts, R., 2021. The acid test: An experimental microarchaeological study of guanodriven diagenesis in tropical cave sediments. Journal of Archaeological Science: Reports, 37, 102947. https://doi.org/10.1016/j.jasrep.2021.102947

McFarlane, D.A., Lundberg, J., 2018. New records of guanoassociated minerals from caves in northwestern Borneo. International Journal of Speleology, 47(2), 119-126. https://doi.org/10.5038/1827-806X.47.2.2169

McKelvey, V.E., 1967. Contributions to economic geology. A summary of salient features of the geology of phosphate deposits, their origin, and distribution. Geological Survey Bulletin 1252-D, 21, 1-21.

Merino, A., Fornós J.J., Mulet, A., Ginés, J., 2019. Morphological and mineralogical evidence for ancient bat presence in Cova des Pas de Vallgornera (Llucmajor, Mallorca, Western Mediterranean). International Journal of Speleology, 48(2), 115-131. https://doi.org/10.5038/1827-806X.48.2.2247

Miko, S., Kuhta, M., Kapelj, S., 2001. Bat guano influence on the geochemistry of cave sediments from Modrič Cave; Croatia. Proceedings of the 13th International Congress of Speleology, Brasilia, p. 187-192.

Miller, C.E., Berthold, C., Mentzer, S.M., Leach, P., Ligouis, B., Tribolo, C., Parkington, J., Porraz, G., 2016. Site-formation processes at Elands Bay Cave, South Africa. Southern African Humanities, 29(1), 69-128.

Monnier, G.F., 2018. A review of infrared spectroscopy in 
microarchaeology: Methods, applications, and recent trends. Journal of Archaeological Science: Reports, 18, 806-823.

https://doi.org/10.1016/j.jasrep.2017.12.029

Muñoz-Dorado, J., Marcos-Torres, F.J., García-Bravo, E., Moraleda-Muñoz, A., Pérez, J., 2016. Myxobacteria: moving, killing, feeding, and surviving together. Frontiers in Microbiology, 7, 781. https://doi.org/10.3389/fmicb

Martinez-Ruiz, F., Jroundi, F., Paytan, A., GuerraTschuschke, I., del Mar Abad, M., González-Muñoz, M.T., 2018. Barium bioaccumulation by bacterial biofilms and implications for $\mathrm{Ba}$ cycling and use of $\mathrm{Ba}$ proxies. Nature Communication, 9, 1619. https://doi.org/10.1038/s41467-018-04069-Z

Nriagu, J.O., 1976. Phosphate - clay mineral relations in soils and sediments. Canadian Journal of Earth Sciences, 13(6), 717-736.

https://doi.org/10.1139/e76-077

Onac, B.P., Vereş D.Ş., 2003. Sequence of secondary phosphates deposition in a karst environment: evidence from Măgurici Cave (Romania). European Journal of Mineralogy, 15, 741-745.

https://doi.org/10.1127/0935-1221/2003/0015-0741

Onac, B.P., Kearns, J., Panzaru, S.C., Breban, R., 2004. Variscite $\left(\mathrm{AlPO}_{4} \cdot 2 \mathrm{H}_{2} \mathrm{O}\right)$ from Cioclovina Cave (Sureneau Mountains, Romania): A tale of a missing phosphate. Studia UBB Geologia, XLIX, 1, 3-14.

http://scholarcommons.usf.edu/tles_publications/855

Onac, B.P., Sumrall, J., Tămaş, T., Povară, I., Kearns, J., Darmiceanu, V., Veres, D., Lascu, C., 2009. The relationship between cave minerals and $\mathrm{H}_{2} \mathrm{~S}$-rich thermal waters along the Cerna Valley (SW Romania). Acta Carsologica, 38, 27-39.

https://doi.org/10.3986/ac.v38i1.135

Onac, B.P., 2012. Minerals. In: White, W.B., Culver, D.C. (Eds.), Encyclopedia of caves ( $2^{\text {nd }}$ Ed.). Academic Press, New York, p. 499-508.

Onac, B.P., 2019. Minerals in caves. In: White, W.B., Culver, D.C., Pipan, T. (Eds.), Encyclopedia of caves (3rd Ed.), Academic Press, New York, p. 699-709.

Pogson, R.E., Osborne, R.A.L., Colchester, D.M., 2014. Minerals of Jenolan Caves, New South Wales, Australia: geological and biological interactions. Proceedings of the Linnean Society of New South Wales, 134, 1-18.

Quattropani, L., Charlet, L., Lumley, H., Menu, M., 1999. Early Paleolithic bone diagenesis in the Arago cave at Tautavel, France. Mineralogical Magazine, 63(6), 801812. https://doi.org/10.1180/002646199548943

Queffelec, A., Bertran, P., Bos, T., Lemée, L., 2018. Mineralogical and organic study of bat and chough guano: implications for guano identification in ancient context. Journal of Cave and Karst Studies, 80(2), 1-17. https://doi.org/10.4311/2017ES0102

Rosina, V.V., 2006. Bats as an indicator of human activity in the Paleolithic, using the example of Denisova Cave, northwestern Altai. Paleontological Journal, 40(4), 494500. https://doi.org/10.1134/S0031030106100091

Sanchez-Moral, S., Luque, L., Cañaveras, J.C., Laiz, L., Jurado, V., Hermosin, B., Saiz-Jimenez, C., 2004. Bioinduced barium precipitation in St. Callixtus and Domitilla catacombs. Annals of Microbiology, 54(1), 1-12.

Sauro, F., Cappelletti, M., Ghezzi, D., Columbu, A., Hong, P.-Y., Zowawi, H.M., Carbone, C., Piccini, L., Vergara, F., Zannoni, D., De Waele, J., 2018. Microbial diversity and biosignatures of amorphous silica deposits in orthoquartzite caves. Scientific Reports, 8, 17569. https://doi.org/10.1038/s41598-018-35532-y

Shahack-Gross, R., Berna, F., Karkanas, P., Weiner, S., 2004. Bat guano and preservation of archaeological remains in cave sites. Journal of Archaeological Science, 31, 1259-1272. https://doi.org/10.1016/j.jas.2004.02.004

Smith, H.E., Morley, M.W., Louys, J., 2020. Taphonomic analyses of cave breccia in Southeast Asia: A review and future directions. Open Quaternary, 6(13), 1-22.

https://doi.org/10.5334/oq.75

Stiner, M.C., Kuhn, S.L., Surovell, T.A, Goldberg, P., Meignen, L., Weiner, S, Bar-Yosef, O., 2001. Bone preservation in Hayonim Cave (Israel): A macroscopic and mineralogical study. Journal of Archaeological Science, 28, 643-659. https://doi.org/10.1006/jasc.2000.0634

Siy, S.E., 1988. Geochemical and petrographic study of phosphate nodules of the Woodford shale (Upper Devonian-Lower Mississippian) of southern Oklahoma. Unpublished MS Thesis, Texas Tech University, 172 p.

Trovillo, K.A., 2015. Bone degradation under differing environments. Unpublished Honors Thesis, University of Tennessee, Knoxville, 20 p.

https://trace.tennessee.edu/utk chanhonoproj/1862

Vaufrey, R., 1929. Les éléphants nains des iles mediterranèennes et la question des isthmus pléistocènes. Archives de 1'Institut de Paléontologie Humaine, 6, 1-220.

Vita, G., 2021. Pleistocene cave paleosols and sediments in northern Sicily. Palaeonvironmental reconstruction. Unpublished Doctoral Thesis in Erasmus Mundus in Quaternary and Prehistory. Universitat Rovira I Virgili, Tarragona, Spain, 170 p.

Weiner, S., Goldberg, P., Bar-Yosef, O., 1993. Bone preservation in Kebara Cave, Israel using on-site Fourier Transform Infrared Spectrometry. Journal of Archaeological Science, 20(6), 613-627.

https://doi.org/10.1006/jasc.1993.1037

Weiner, S., Goldberg, P., Bar-Yosef, O., 2002. Threedimensional distribution of minerals in the sediments of Hayonim Cave, Israel: diagenetic processes and archaeological implications. Journal of Archaeological Science, 29, 1289-1308. https://doi.org/10.1006/jasc.2001.0790

Westermann, S., Föllmi, K., Matera, V., Adatte, T., 2007. Phosphorus and trace-metal records during Cretaceous oceanic anoxic events: Example of the Early Aptian OAE in the western Tethys. Carnets de Geologie. In: Bulot, L.G., Ferry, S., Grosheny, D. (Eds.), Relations entre les marges septentrionale et méridionale de la Téthys au Crétacé. Carnets de Géologie/Notebooks on Geology, CG2007_M02/03, p. 20-22.

White, W.B., 1982. Mineralogy of the Butler Cave-Sinking creek system. National Speleological Society Bulletin, 44(3), 90-97.

Wurster, C.M., Munksgaard, N., Zwart, C., Bird, M.I., 2015. The biogeochemistry of insectivorous cave guano: a case study from insular Southeast Asia. Biogeochemistry, 124, 163-175. https://doi.org/10.1007/s10533-015-0089-0

Yll, R., Carrion, J.S., Marra, A.C., Bonfiglio, L., 2006. Vegetation reconstruction on the basis of pollen in Late Pleistocene hyena coprolites from San Teodoro Cave (Sicily). Palaeogeography, Palaeoclimatology, Palaeoecology, 237, 32-39. https://doi.org/10.1016/j.palaeo.2005.11.027 